\title{
Successful in a conservative treatment of osteoradionecrosis of the jaw: a case report and review of literature
}

\author{
Sucesso no tratamento conservador de osteorradionecrose dos maxilares: relato de caso e revisão da \\ literatura
}

Paulo de Camargo MORAES 1

Luiz Alexandre THOMAZ1

Milena Bortolotto Felippe SILVA'

José Luiz Cintra JUNQUEIRA' ${ }^{1}$

Rubens Gonçalves TEIXEIRA'

\begin{abstract}
Osteoradionecrosis of jaws is one of the most serious complications of radiation therapy for head and neck malignancies. The management of osteoradionecrosis continues to be debated and there are few cases which can be resolved with conservative management. This paper presents a case of osteoradionecrosis after a dental extraction affecting the mandible of a 58-year-old man and highlights the conservative therapeutic management and 3-year follow-up period. We combined a conservative nonoperative therapy, including long-term antibiotic therapy and daily irrigation with chlorhexidine mouthrinses in a case of osteoradionecrosis after a dental extraction affecting the mandible of a 58-year-old man. At the follow-up, clinical aspect was resolved. A CBCT scan image and a three-dimensional (3D) reconstructed image revealed bone remodeling in a 3-year follow-up period. No sign of exposed bone could be seen. Follow-up 3 years later revealed that the conservative management posed was successful for osteoradionecrosis and the patient is currently under regular review.
\end{abstract}

Indexing terms: osteoradionecrosis. cone beam computed tomography. treatment.

\section{RESUMO}

Osteorradionecrose dos maxilares é uma das complicações mais sérias da radioterapia para o tratamento de tumores de cabeça e pescoço. O manejo da osteorradionecrose continua sendo discutido e há poucos relatos de casos descrevendo modalidades de tratamento conservadoras. Este artigo apresenta um caso de osteorradionecrose na mandíbula de um paciente de 58 anos de idade, após a realização de exodontia e explora uma modalidade de tratamento conservador com um follow-up de três anos. Foram combinadas antibioticoterapia e irrigação diária utlizando clorexidina. Após três anos é possível observar a resolução do caso em imagens de tomografia computadorizada de feixe cônico e reconstruções 3D. As imagens evidenciam remodelação óssea após este período de acompanhamento e sem a presença de osso exposto. Pode-se concluir que a terapia proposta resultou em sucesso e o paciente continua em acompanhamento periódico.

Termos de indexação: osteorradionecrose. tomografia computadorizada de feixe cônico. tratamento.

\section{INTRODUCTION}

Osteoradionecrosis is defined as severe delayed radiation-induced injury, characterized by bone tissue necrosis and failure to heal' ${ }^{1}$. According to a recent report osteoradionecrosis rates vary from 1 to $9 \%$, and may be decreased by using a 21-day delay between extractions and irradiation, provided that it does not postpone cancer treatment, with a dose-dependent risk $(<6 \%$ if $<40 \mathrm{~Gy}$; $14 \%$ between 40 et $60 \mathrm{~Gy}$; or $=20 \%$ if $>60 \mathrm{~Gy})^{2}$. It occurs spontaneously (35\%), mostly involves the mandibula (85\%).

The diagnosis of ORN can be made based on clinical signs and symptoms of ulceration or necrosis on the mucosa, with exposure of necrotic bone for more than 3 months in irradiated patients. Pain, trismus, and

\footnotetext{
${ }^{1}$ Faculdade São Leopoldo Mandic, Curso de Odontologia, Programa de Pós-Graduação em Odontologia. Rua José Rocha Junqueira, 13, 13045-755, Swift, Campinas, SP, Brasil. Correspondência para / Correspondence to: PC MORAES. E-mail: <pcmdent@ig.com.br>.
} 
suppuration in the area of the lesion may be present ${ }^{3}$. Progression of ORN can lead to pathologic fracture and intraoral and/or extraoral fistula ${ }^{4}$. Xerostomia, dysgeusia, dysphagia, decreased tongue mobility were also described as symptoms from ONR. These problems often leave patients physically and emotionally disabled ${ }^{5}$. Radiological images include decreased bone density and occasionally fracture. Computerized tomography (CT) scans shows osseous abnormalities such as focal lytic areas cortical interruptions and loss of the spongiosa trabeculation on the symptomatic side, frequently accompanied by soft tissue thickening ${ }^{6}$

The literature showing conflicting results when compared tooth extractions before and after radiotherapy. Koga et al. ${ }^{7}$ evaluated the frequency of ORN associated with dental extractions. A total of 405 patients submitted to radiotherapy and had dental were evaluated. It was found a low prevalence of ORN. Only 2 ORN (0.5\%) cases associated with 1647 exodontia performed before radiotherapy and 1 ORN case (1.7\%) in 290 exodontias after irradiation. These results point to the possibility of performing exodontias in irradiated patients. The osteoradionecrosis were observed significantly earlier in patients who received pre-surgical radiotherapy than those who received post-surgical radiotherapy ${ }^{8}$. Agbaje et al. ${ }^{9}$ demonstrated the delayed bone healing after tooth extraction in irradiated head and neck cancer patients in a pilot study and concluded the healing process is slower in patient undergoing radiotherapy. A potential effect of radiotherapy on further jaw $b$ one healing after pretherapeutic tooth extractions should be considered in the treatment planning.

Koga et al. ${ }^{10}$ discussed the literature regarding dental extractions performed before and after head and neck radiotherapy and concluded that before making the decision to extract teeth before or after radiotherapy, the individual characteristics of the patients, tumor and oncological treatment should be considered. Oral evaluation before radiotherapy reduces the risk of complications and dental extractions should be preferably is performed before commencement of irradiation. In addition, the authors emphasized that a multidisciplinary team consisting of radiotherapist, oral and maxillofacial surgeon, head and neck surgeon, and oncologist is mandatory.

The management of ONR remains a difficult and challenging problem ${ }^{11}$. Several therapies have been investigated for the treatment of ORN, with varying results. Conservative treatment includes nonoperative (ie, improvement of oral hygiene, antibiotics, and analgesics). It is usually recommended in the case of early and localized lesion that is not progressing with minimal symptoms ${ }^{3,12}$. Hyperbaric oxygen therapy could be an adjunct ${ }^{12-13}$. Advance disease commonly requires a radical resection and reconstruction ${ }^{2}$. Recently, many new innovations have been reported, including ultrasound, biological molecules, distraction osteogenesis and antioxidant agents ${ }^{12}$ Mcleod et al. ${ }^{14}$ presented the outcomes of patients with ORN prescribed pentoxifylline and tocopherol. Pentoxifylline inhibits tumor necrosis factor alpha (TNF-alpha), and tocopherol is a scavenger of reactive oxygen species. This therapy has shown a positive synergistic effect on the progression of ORN.

This paper presents a case of ORN after a dental extraction affecting the mandible of a 58-year-old man and highlights the conservative therapeutic management and 3-year follow-up period.

\section{CASE REPORT}

A 58-year-old male was referred to the Stomatology Department of São Leopoldo Mandic Dental School, Campinas, Brazil regarding pain in the mandible and difficult in swallowing and extraoral fistulae can be observed. Squamous cell carcinoma in the lower lip had been diagnosed in January 2000. Metastasis had been diagnosed in November 2000. Surgical removal of nodes of the neck was made. The patient received radiation therapy (25 sessions of radiotherapy with a total dose of 4.500 cGy). The tooth 47 had been extracted five years after radiotherapy finished but the alveolar socket no healing and occurred bone exposure in this local.

Figure 1 shows the panoramic radiograph before the tooth extraction. Because of the tissue necrosis a fistulous developed extra orally (Figure 2). Clinical examination revealed pain, trismus, bone exposure, and fistula formation at the right mandibular second molar (Figure 3). Panoramic radiograph and computerized tomography (CBCT) images revealed irregular sclerotic bone at the right mandibular second molar due to osteoradionecrosis (Figure 4 and Figure 5A).

The possibilities of surgical and conservative therapy were thoroughly discussed with the patient, and the patient opted for conservative management, initially a culture and antibiogram was made and the patient was treated by conservative nonoperative therapy, including 
long-term antibiotic therapy (Cloranfenicol $500 \mathrm{mg}$, three times per day during 12 days) and daily irrigation with chlorhexidine 0.12 mouthrinses. At the followup, clinical aspect was resolved. A CT scan image and A Three-dimensional (3D) reconstructed image revealed

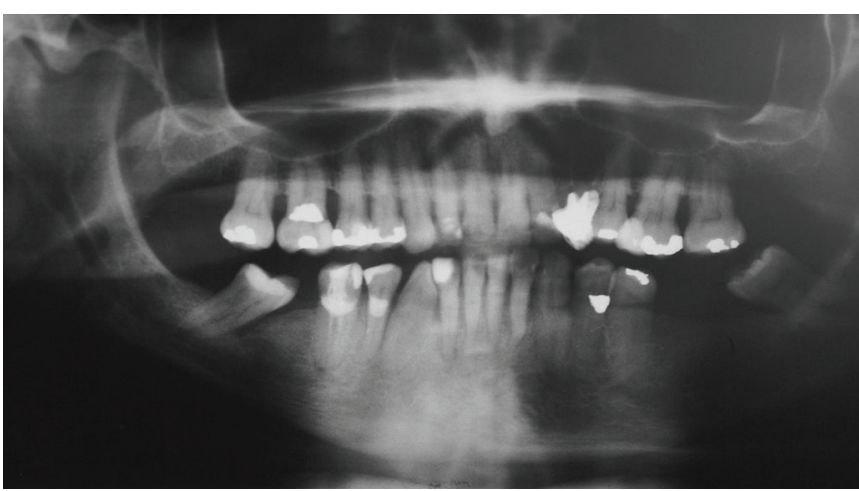

Figure 1. Panoramic radiograph before the tooth extraction.

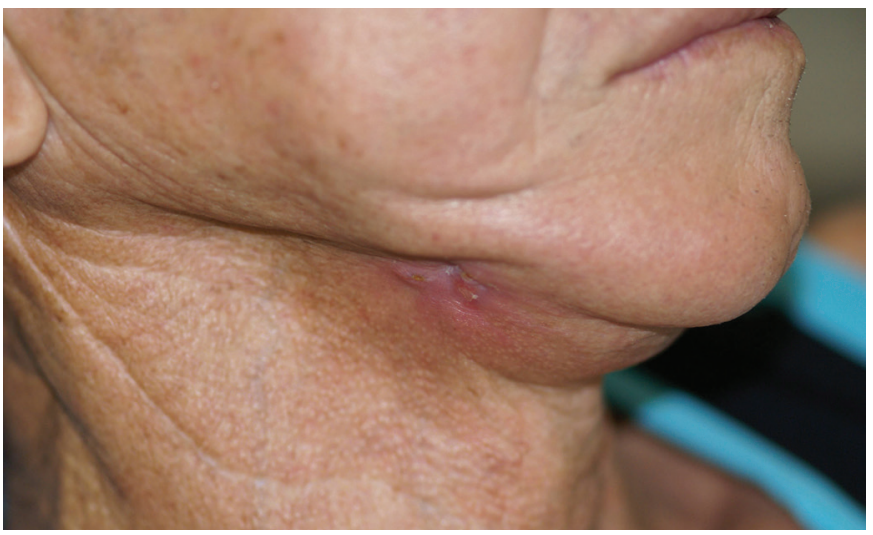

Figure 2. Extraoral view showing fistulous and swelling. bone remodeling in a 2-year follow-up period (Figures 5B e $5 C$ ). No sign of exposed bone could be seen. Follow-up 3 years later revealed that the conservative management was successful for ORN (Figures $6 \mathrm{~A}, 6 \mathrm{~B}, 6 \mathrm{C}$ ) and the patient is currently under regular review.

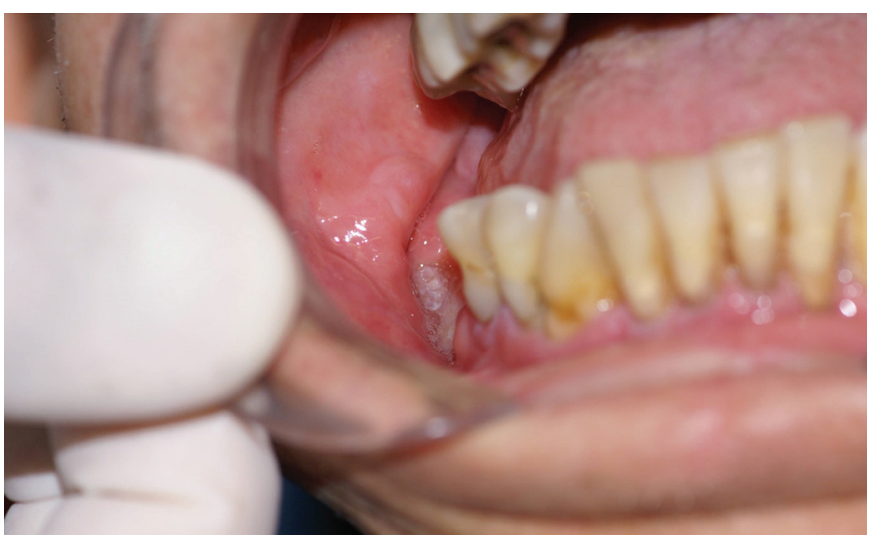

Figure 3. Clinical appearance of exposed bone at the right mandibular second molar.

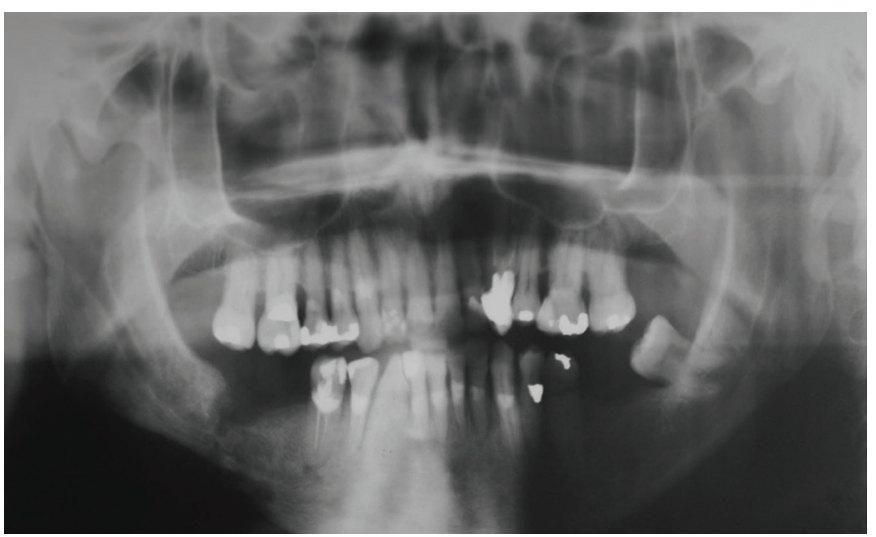

Figure 4. Panoramic radiograph showing irregular sclerotic bone at the right mandibular second molar (osteomyelitis). 

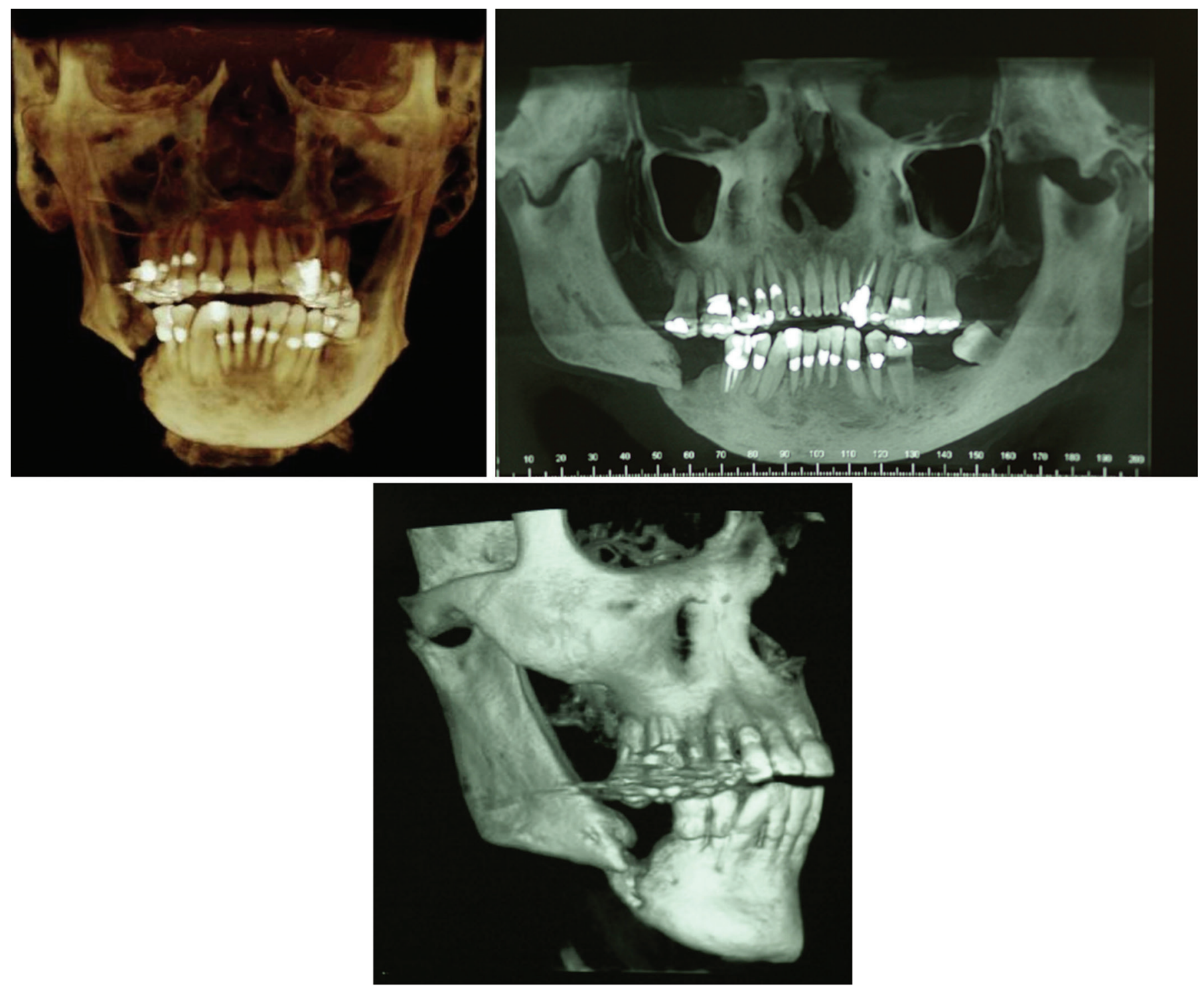

Figure 5. A) A Three-dimensional (3D) reconstructed image showed irregular sclerotic bone at the right mandibular second molar due to osteorradionecrosis. B and C. A CT scan image and a three-dimensional (3D) reconstructed image revealed bone remodeling in a 2-year follow-up period. 

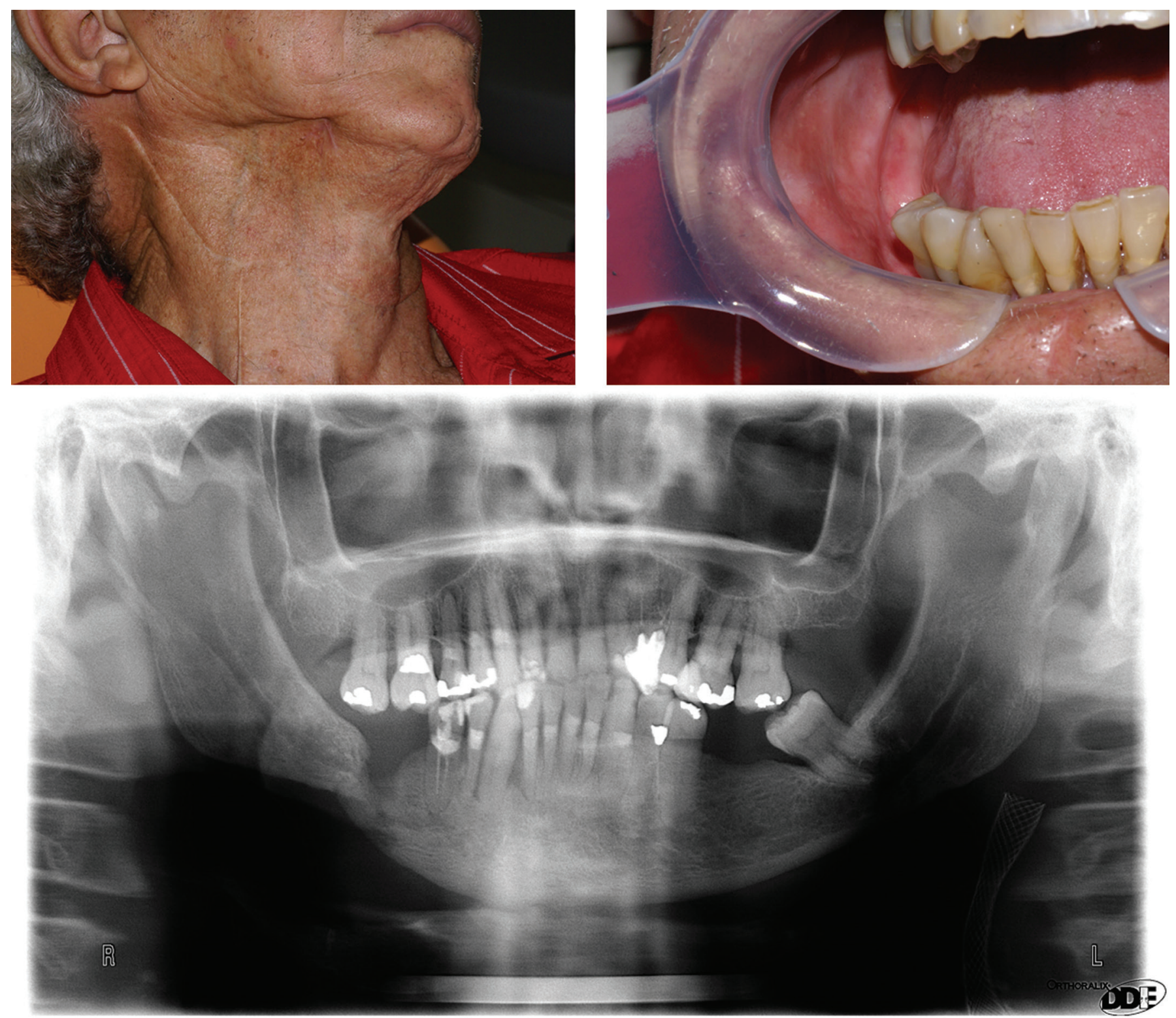

Figure 6. A, 6 B e 6 C. Extra and intraoral aspects in a 3-year follow-up period.

\section{DISCUSSION}

ORN was first described by Regaud in $1922^{15}$. Although the pathogenesis of ORN is not completely understood, it has not been considered as a primary infection of the irradiated bone, but a metabolic and tissue homeostatic deficiency created by radiation-induced cellular injury, characterized by the sequence of radiation, the formation of hypoxic, hypovascular, and hypocellular tissue, followed by tissue breakdown, and resulting in a chronic, nonhealing wound ${ }^{16}$. More recent findings in the elucidation of the pathophysiology of lesions in osteoradionecrosis have focused on the presence of radiation-induced fibrosis. The dysregulation of fibroblastic activity in irradiate area produces atrophic tissue with damage to microvessels, and allows increased leakage of inflammatory mediators ${ }^{14}$. The mandible is one of the most frequently affected bones $2,6,11,17-19$.

ORN has been reported as the major complication of irradiation in head and neck cancer $2,5-7,11,13,20-22$. However, many etiologic factors of ORN have been reported in the 
literature. According to Kluth et al. ${ }^{23}$ ORN can occur through a combination of factors such as tumor site, extraction site, denture irritation, and/or surgery. Oh et al. ${ }^{11}$ reported that $43 \%$ of ORN cases occurred spontaneously or through unknown causes.

Although ORN can occur at any time after radiotherapy, it is most frequently noted in the first few years after completion of treatment (70-94\%) ${ }^{8}$. In the present case patient reported that he received radiotherapy 6 years before and with a total dose of 4.500 cGy and the tooth 47 had been extracted in a dental school five years after radiotherapy finished. Thorn et al.24 evaluated 80 cases of ORN and verified that in $93 \%$ of these cases the radiation dose were $>6400 \mathrm{cGy}$. Advances in the delivery of radiation therapy (i.e. Intensity modulated radiation therapy - IMRT) holds promise to decrease the incidence of ORN by increasing the conformality of the high dose prescription to spare larger volumes of mandible and improve homogeneity of dose ${ }^{5}$. No cases of ORN were observed in a previous series of IMRT for head and neck cancer ${ }^{25}$.

According to the literature review ORN does not exist universally as a single discrete entity but as parts among a spectrum of injury severity and consequently is responsive to differing treatments of varying invasiveness ${ }^{26}$. The treatment of ORN can be frustrating for the patients because they often must endure repeated interventions without a clear end in sight $^{5}$. Pitak-Arnnop et al. ${ }^{12}$ discussed the management of jaw bone osteoradionecrosis based on levels of evidence. Most of the reports on the treatment of ORN offer weak evidence. According to the authors, current information seems insufficient for establishing the treatment guidelines and well-designed studies with long term clinical data are needed. In the present case, we report a case treated in our service of mandibular ORN after tooth extraction. The present case can be considered a severe ORN due to the symptoms, bone features and extraoral fistula. ORN responded to conservative treatment proposed and CT scan showed bone remodeling in a 3-year follow-up period. There are few reports in literature in which ONR were resolved with conservative management.
Osteoradionecrosis affects the quality of life and produces significant morbidity in afflicted patients ${ }^{27}$. Prevention of ORN is essential for the management of patients who undergo external beam radiation therapy to the head and neck. All patients should be informed and received prophylactic oral health care prior to, during, and after the completion of radiation therapy. A recent retrospective cohort study of 1759 patients with head and neck cancer in Taiwan concluded that a tooth extraction time less than half a year after head and neck radiotherapy or during the head and neck radiotherapy period, and extraction tooth number $\leq 5$ would significant lower the ORN prevalence. ${ }^{28}$ Multidisciplinary approach is mandatory in the management of the patient. Further improvement in therapeutic and treatment options is required in order to reduce ORN complications and its negative impact on the quality of life.

\section{CONCLUSION}

In conclusion, follow-up 3 years later revealed that the conservative management posed was successful for osteoradionecrosis and the patient is currently under regular review.

\section{ACKNOWLEDGEMENT}

We thank Dr. Marcio Inacarato for his help regarding the analysis of $C B C T$ images.

Collaborators

PC MORAES, LA THOMAZ, and RG TEIXEIRA assisted the patient in the case here reported and in writing the paper. MBF SILVA and JLC JUNQUEIRA contributed to the acquisition of $\mathrm{CBCT}$ and then interpretation. All authors made substantial contributions to all stages of this paper and approved the final version and its submission to this journal.

\section{REFERENCES}

1. Chrcanovic BR, Reher $P$, Sousa AA, Harris $M$ Osteoradionecrosis of the jaws - a current overview part 2: dental management and therapeutic options for treatment. Oral Maxillofac Surg. 2010;14(2):81-95. doi: 10.1007/ s10006-010-0205-1.

2. Thariat J, De Mones E, Darcourt V, Poissonnet G, Dassonville $O$, Savoldelli $C$, et al. Teeth irradiation in head and neck cancer. Cancer Radiother. 2010;14(2):128-36.

3. Nakatsuka T, Harii K, Yamada A, Ueda K, Ebihara S, Takako T. Surgical treatment of mandibular osteoradionecrosis: versatility of the scapular osteocutaneous flap. Scand J Plast Reconstr Hand Surg. 1996;30(4):291-8 
4. Shaha AR, Cordeiro PG, Hidalgo DA, Spiro RH, Strong EW, Zlotolow I, et al. Resection and immediate microvascular reconstruction in the management of osteoradionecrosis of the mandible. Head Neck. 1997;19(5):406-11.

5. Jacobson AS, Buchbinder D, Hu K, Urken ML. Paradigm shifts in the management of osteoradionecrosis of the mandible. Oral Oncol. 2010;46(11):795-801. doi: 10.1016/j. oraloncology.2010.08.007

6. Jereczek-Fossa BA, Orecchia R. Radiotherapy-induced mandibular bone complications. Cancer Treat Rev. 2002;28(1):65-74. doi:10.1053/ctrv.2002.0254

7. Koga DH, Salvajoli JV, Kowalski LP, Nishimoto IN, Alves FA. Dental extractions related to head and neck radiotherapy: ten-year experience of a single institution. Oral Surg Oral Med Oral Pathol Oral Radiol Endod. 2008;105(5):e1-6. doi: 10.1016/j.tripleo.2008.01.007

8. Reuther T, Schuster T, Mende U, Kübler A. Osteoradionecrosis of the jaws as a side effect of radiotherapy of head and neck tumor patients - a report of a thirty year retrospective review. Int J Oral Maxillofac Surg. 2003;32(3):289-95. doi:10.1054/ ijom.2002.0332

9. Agbaje JO, Jacobs $R$, Michiels K, Abu-Ta'a M, van Steenberghe D. Bone healing after dental extractions in irradiated patients: a pilot test on a novel technique for volume assessment of healing tooth sockets. Clin Oral Invest. 2009;13(3):257-61. doi: 10.1007/s00784-008-02317

10. Koga DH, Salvajoli JV, Alves FA. Dental extractions and radiotherapy in head and neck oncology: review of the literature. Oral Dis. 2008;14(1):40-4. doi: 10.1111/j.16010825.2006.01351.x

11. Oh HK, Chambers MS, Martin JW, Lim HJ, Park HJ. Osteoradionecrosis of the mandible: treatment outcomes and factors influencing the progress of osteoradionecrosis. J Oral Maxillofac Surg 2009;67(7):1378-86. doi: 10.1016/j. joms.2009.02.008

12. Pitak-Arnnop P, Sader R, Dhanutai K, Masaratana P, Bertolus $C$, Chaine A, et al. Management of osteoradionecrosis of the jaws: an analysis of evidence. Eur J Surg Oncol 2008;34(10):1123-34. doi: 10.1016/j.ejso.2008.03.014

13. Vudiniabola S, Pirone C, Williamson J, Goss AN. Hyperbaric oxygen in the manangement of osteoradionecrosis of the facial bones. Int J Oral Maxillofac Surg. 2000;29(6):435-8. doi:10.1016/S0901-5027(00)80075-2

14. Mcleod NMH, Pratt CA, Mellor TK, Brennan PA. Pentoxifylline and tocopherol in the management of patients with osteoradionecrosis, the Portsmouth experience. $\mathrm{Br} J$ Oral Maxillofac Surg. 2012;50(1):41-4. doi: 10.1016/j. bjoms.2010.11.017

15. Regaud C. Sin la necrose des os attrens par un processus cancereux et traits par les radiations. Compt Rend Soc De Biol. 1922;87:427.

16. Marx RE. Osteoradionecrosis: a new concept of its pathophysiology. J Oral Maxillofac Surg. 1983;41(5):283. doi:10.1016/0278-2391(83)90294-X
17. Vanderpuye $V$, Goldson A. Osteoradionecrosis of the mandible. J Natl Med Assoc. 2000;92(12):579-84.

18. Hancock PJ, Epstein JB, Sadler GR. Oral and dental management related to radiation therapy for head and neck cancer. J Can Dent Assoc. 2003;69(9):585-90.

19. Jham BC, Freire ARS. Oral complications of radiotherapy in the head and neck. Rev Bras Otorrinolaringol. 2006;72(5):7048.

20. Németh Z, Somogyi A, Takácsi-Nagy Z, Barabás J, Németh G, Szabó G. Possibilities of preventing osteoradionecrosis during complex therapy of tumors of the oral cavity. Pathol Oncol Res. 2000;6(10):53-8. doi: 10.1053.paor.2000.0227

21. Vissink A, Jansma J, Spijkervet FKL, Burlage FR, Coppes RP. Oral sequelae of head and neck radiotherapy. Crit Rev Oral Biol Med 2003;14(3):199-212. doi: 10.1177/154411130301400305

22. Park $C W$, Jin $B J$, Jeong $S W$, Min $H J$, Shin JH, Lee $S H$. CSF Otorrhea resulting from osteoradionecrosis of the temporal bone in a patient with recurrent meningioma. Clin Exp Otorhinolaryngol. 2009;2(2):97-9. doi: 10.3342/ ceo.2009.2.2.97

23. Kluth EV, Jain PR, Stuchell RN, Frich JC Jr. A study of factors contributing the development of osteoradionecrosis of the jaws. J Prosthet Dent. 1988;59(2):194-201. doi: 10.1016/0022-3913(88)90015-7

24. Thorn JJ, Hansen HS, Specht L, Bastholt L. Osteoradionecrosis of the jaws; clinical characteristics and relation to the field of irradiation. J Oral Maxillofac Surg 2000;58(10):1088-1093. doi: 10.1053/joms.2000.9562

25. Ben-David MA, Diamante $M$, Radawski JD, Vineberg KA, Stroup C, Murdoch-Kinch CA, et al. Lack of osteoradionecrosis of the mandible after IMRT for head and neck cancer ; likely contributions of both dental care and improved dose distributions. Int J Radiat Oncol Biol Phys. 2007;68(2):396-402. doi: 10.1016/j.jjrobp.2006.11.059

26. Wong JK, McLean M. Conservative management of osteoradionecrosis. Oral Surg Oral Med Oral Pathol Oral Radiol Endod. 1997;84(1):16-21. doi: 10.1016/S10792104(97)90287-0

27. Ruggiero SL, Dodson TB, Assael LA, Landersberg R, Marx RE, Mehrotha B. American Association of Oral and Maxillofacial Surgeons position paper on bisphosphonate-related osteonecrosis of the jaws - 2009 update. J Oral Maxillofac Surg 2009;67:2-12. doi: 10.1016/j.joms.2009.01.009

28. Kuo TJ, Leung CM, Chang HS, Wu CN, Chen WL, Chen GJ, et al. Jaw osteoradionecrosis and dental extraction after head and neck radiotherapy: A nationwide population-based retrospective study in Taiwan. Oral Oncol. 2016;56:71-7. doi: 10.1016/j.oraloncology.2016.03.005

Received on:17/9/2015

Final version resubmitted on: 11/11/2015 Approved on: 7/2/2016 